\title{
Inhibiting Factors of Confiscation of Assets Proceeds of Corruption by the Prosecutor's Office: Studies in Indonesia
}

Syahiruddin Latif*

Faculty of Law, Nahdlatul Ulama University of Southeast Sulawesi, Indonesia

\author{
DOI: $10.36348 /$ sijlcj.2020.v03i11.008 \\ | Received: 05.11.2020 | Accepted: 16.11.2020 | Published: 19.11 .2020 \\ *Corresponding author: Syahiruddin Latif
}

Abstract

This paper aims to analyze the factors that hamper law enforcement of confiscation of assets resulting from criminal acts of corruption as an effort to recover state losses by the Prosecutor's Office. The type of research used is normative legal research with a statutory approach, the data used are secondary data collected through literature search and document study. The collected data were then analyzed qualitatively and then described. The results of this study indicate that in practice there are several obstacles in enforcing the law of confiscation of assets resulting from criminal acts of corruption as an effort to recover state losses by the Attorney, these obstacles are strongly influenced by legal factors, law enforcement factors, supporting facilities. community factors, and cultural factors.

Keywords: Confiscation of assets, corruption crimes, inhibiting factors, prosecutors.

Copyright () 2020 The Author(s): This is an open-access article distributed under the terms of the Creative Commons Attribution 4.0 International License (CC BY-NC 4.0) which permits unrestricted use, distribution, and reproduction in any medium for non-commercial use provided the original author and source are credited.

\section{INTRODUCTION}

Every state loss is caused by perpetrators of corruption, both those that are still in the country and those already outside the country must be returned, through the mechanism of international cooperation which is an absolute thing to do [1]. In general, criminal offenders try to hide or disguise the origin of assets that are the result of criminal acts in various ways so that the assets from criminal acts are difficult to track down by law enforcement officials so that the perpetrators of these crimes can freely utilize these assets, both for both legitimate and illegitimate activities. Therefore, the crime of money laundering not only threatens the stability and integrity of the economic system and financial system, but also endangers the joints of community, nation and state life based on the Pancasila and the 1945 Constitution of the Republic of Indonesia [2]. Syed Hussein Alatas [3] defines that "Corruption is the subordination of the public interest under the interests of private goals which includes violation of norms, duties and public welfare, coupled with secrecy, betrayal, fraud and extraordinary ignorance of the consequences suffered by society. In short, corruption is the abuse of trust for personal gain".

Yusuf L. Indradewa [4] believes that there are three problems contained in Article 23 paragraph (5) of the 1945 Constitution, namely: (1) There are state financial responsibilities that must be examined; (2) For the said accountability examination, a State Audit Board shall be established, the regulations of which are stipulated by law, and (3) The results of the examination shall be notified to the House of Representatives.

The Asset Confiscation Bill is aimed at pursuing the proceeds of crime, not against criminals [5]. Based on this description, the issues discussed in this paper are what factors are the obstacles to law enforcement of confiscation of assets resulting from criminal acts of corruption as an effort to recover state losses by the Attorney General's Office.?

\section{RESEARCH METHOD}

The type of research used is normative legal research with a statutory approach [6], The data used are secondary data collected through literature search and document study. The collected data were then analyzed qualitatively [7] and then described.

\section{RESULTS AND DISCUSSION}

The law enforcement pattern of confiscation of assets resulting from criminal acts of corruption as an effort to recover state losses by the Prosecutor's Office, namely through asset tracking, freezing and confiscation of assets, management and confiscation of 
assets, transfer of assets, and supervision and utilization of assets are the maximum efforts of law enforcers in saving state assets. However, in practice there are several obstacles in enforcing the law of confiscation of assets resulting from corruption crimes, these obstacles are strongly influenced by the following factors:

\section{Legal Factors}

Article 10 paragraph (2) letter b of the Criminal Code (KUHP) regulates that confiscation of confiscated property is an additional punishment determined by the court after obtaining a decision which has permanent legal force. Meanwhile, Article 39 of the Criminal Procedure Code (KUHAP) regulates the types of goods that may be subject to confiscation, namely:

1. Assets resulting from a criminal act;

2. Confiscated assets obtained from the accused;

3. Objects or claims that are entirely or partly alleged to have been obtained from a criminal act or as the result of a criminal act;

4. Used directly to commit a criminal act or to prepare it;

5. Objects that are used to obstruct a criminal investigation;

6. Objects made or intended to commit a criminal act;

7. Other objects that have a direct relationship with the criminal act committed.

Furthermore, Article 44 of the Criminal Code states that:

1. The confiscated goods are kept in the state storage house for seized goods;

2. The storage of confiscated goods is carried out properly and the responsibility for it rests with the authorized official according to the level of examination in the judicial process and the said objects are prohibited from being used by anyone.

Then Article 46 of the Criminal Procedure Code states that:

1. Items subject to confiscation must be returned if:

a) Objects are no longer required for the purpose of investigation and prosecution;

b) The case was not prosecuted because there was insufficient evidence;

c) Cases are set aside for public interest or closed for the sake of law.

2. If the case has been decided, the objects subject to confiscation shall be returned unless according to the judge's decision the goods were confiscated for the state

Furthermore, in Article 194 paragraph (1) of the Criminal Procedure Code it is stipulated that "in the case of a conviction or acquittal or acquittal of all legal claims, the court determines that the confiscated evidence is handed over to the party most entitled to receive back whose name is stated in the decision unless according to the provisions. This law is confiscated for the benefit of the state or destroyed or damaged so that it cannot be used again".

Article 273 paragraph (3) of the Criminal Procedure Code stipulates that "the public prosecutor shall authorize objects to the state auction office and within three months for sale to auction ...". Therefore, the loot assets had to be sold at the state auction office.

In contrast to the criminal act of corruption, in the crime of money laundering regulated in the Law of the Republic of Indonesia Number 8 of 2010 concerning the Prevention and Eradication of the Crime of Money Laundering, there are no specific provisions regarding items that can be confiscated assets. Therefore what applies is the provisions contained in Article 39 paragraph (1) of the Criminal Code which means that only goods that can be confiscated are [8]: the crime;

a. Items belonging to the convict obtained from

b. The convict's property which was deliberately used to commit a crime.

In the crime of money laundering, namely in Articles 3, 4 and 5 of Law of the Republic of Indonesia Number 8 Year 2010 concerning the Prevention and Eradication of the Crime of Money Laundering, there is an element of "it is known or should reasonably be suspected of being the result of a criminal act".

The not yet ratified of the Draft Law on Confiscation of Criminal Assets is one of the legal factors in obstructing law enforcement of confiscation of assets resulting from criminal acts of corruption as an effort to recover state losses by the Kendari District Attorney, not to mention the problems in Law of the Republic of Indonesia Number 20 Year 2001 concerning Amendments on Law of the Republic of Indonesia Number 31 Year 1999 concerning Eradication of Corruption Crime which is a more specific rule of the Criminal Code relating to corruption.

The thing that makes it difficult to maximize the return of money for corruption crimes to the state is because the Law of the Republic of Indonesia Number 20 Year 2001 concerning Amendments to the Law of the Republic of Indonesia Number 31 Year 1999 concerning Eradication of Corruption Crimes has limited the amount of replacement money that can be paid equal to money obtained from corruption crimes or as much as can be proven in court [9]. This suggests that the Bill on Confiscation of Criminal Assets must be promulgated for maximum enforcement of the confiscation of assets resulting from criminal acts of corruption as an effort to recover state losses.

\section{Law Enforcement Factors}

There are three phenomena covered in the term corruption: bribery, extortion, and nepotism. The three 
types are different, but there is a common thread that connects the three types of corruption, namely the placement of public interests under personal goals with violations of the norms of duty and welfare, accompanied by confidentiality, betrayal, fraud, and neglect of the public interest [10]. Law enforcers are people who make real efforts to uphold or function legal norms according to the applicable rules as guidelines for legal relations, but in social life there are law enforcement officers who do not have firmness regarding perpetrators of corruption, according to Sunarto's explanation in In social life, there are law enforcement officers who do not have firmness about the perpetrators of corruption who are considered white-collared criminals and are difficult to arrest by law enforcement officials because corruptors have various accesses to hide the proceeds of the criminal act of corruption, so law enforcement officers who Having high professionalism that specifically handles corruption is very much needed to support the eradication of real corruption in the confiscation of assets convicted of corruption as an effort to return the state [11].

Among the methods used in Indonesia to hide proceeds from crime by the perpetrators of criminal acts of corruption are [12]:

(1) Real estate/immovable assets

(2) Corrupt officials or criminals who make a lot of money tend to use funds obtained from the proceeds of crime to buy immovable property on behalf of the real owner or by including a third party in the name of a relative or ally. Property transactions can be manipulated to use visible capital proceeds to disguise the illicit funds.

(3) Purchase of valuables (gold)

Corruption funds can be used to purchase valuables such as cars, precious metals and jewelery, so investigators and prosecutors must determine the ownership, value and source of the funds used to purchase these items.

(4) Domestic shares

Publicly listed domestic shares can be bought and sold by a stockbroker. Orders are placed with brokers looking for partners who trade shares with clients. If two parties agree to buy and sell shares, the buy-sell order is signed by the parties concerned. After the transaction is agreed upon, one document is registered on the stock exchange. The document contains details about the buyer and seller, and the terms and conditions of sale. There is also a separate sales deed that is signed by the seller. The fair commission paid to brokers is $1.5 \%$ of the total sales price. Taxes may also need to be paid. Shareholders will issue a receipt to both the buyer and seller specifying the details of the transaction. The documentation involved in this process includes a detailed profile of buyers and sellers. These details include the character, address, signature, title, telephone number and names of the fathers and grandfathers. The company maintains one detailed record of its shareholders.

Thus, it requires law enforcement officers who have high professionalism in carrying out their duties and functions as representatives of the state in enforcing the law.

\section{Supporting Facility Factor}

Supporting facilities owned by law enforcement officials, especially the prosecutor's office, are very important, the prosecutor's office acts as a state lawyer and has the authority to execute state assets confiscated from perpetrators of corruption has a heavy burden, especially when the prosecution is not equipped with supporting facilities in carrying out law enforcement. Without supporting facilities and facilities, it will be increasingly difficult for prosecutors to carry out their law enforcement duties of confiscating assets resulting from criminal acts of corruption as an effort to recover state losses.

Assets that can be confiscated are adjusted to the types of criminal acts involved, namely including [13]:

1. Any assets resulting from a criminal act or obtained from a criminal act; and or

2. Assets used as tools, facilities, or infrastructure to commit a criminal act or support a criminal organization; and or

3. Any assets related to criminal acts or criminal organizations; and or

4. Assets used to finance criminal acts or criminal organizations; and or

5. Everything that belongs to the perpetrator of a criminal act or a criminal organization;

6. illicit enrichment owned by a public official.

Asset confiscation was also carried out, as a result of several things, among others [14]:

1. The owner of the asset has passed away;

2. The criminal process ends because the defendant is acquitted;

3. Criminal prosecution occurred and was successful but asset acquisition was not successful;

4. The defendant is not within the boundaries of jurisdiction, the name of the owner of the assets is not known; and

5. There is no sufficient evidence to initiate a criminal suit

In carrying out information tracing, investigators or public prosecutors together with prosecutors, state lawyers can request information and documents from any person or government agency. Every person or government agency is obliged to provide information and documents to the investigator or public prosecutor. Any person or government agency is prohibited from informing other parties, either directly or indirectly in any way, regarding requests and 
provision of information and documents [15]. Therefore, to maximize the task of enforcing the law of confiscation of assets resulting from corruption as an effort to recover state losses, the prosecutor's office needs to be equipped with adequate supporting facilities and facilities to support its duties.

\section{Community Factors}

Deviation of behavior or standard deviation, which violates or is against the law. Therefore, in the context of overcoming criminal acts, social control is needed[16]. Society is a group of people who form a semi-closed system, where most of the interactions are between individuals who are in the group. According to Shaykh Taqyuddin An-Nabhani, a group of people can be said to be a society if they have the same thoughts, feelings, and systems or rules. Humans then interact with each other based on benefit. According to Sunarto, the public still has the wrong paradigm which states that perpetrators of corruption are a common act so that it can take so long and continue to increase if left alone, it will even become a contagious disease for the nation's successor as regeneration, but on the other hand, the community does not know that perpetrators of criminal acts of corruption have very broad and systematic access in carrying out these actions [17].

The community has a role in helping to provide information that they know to the prosecutor regarding the assets of the perpetrators of corruption, whether the perpetrators are family, friends, colleagues, neighbors or other parties, but they know the ins and outs of the assets that the person has acquired. The lack of openness of the public to the information required by law enforcement officials is one of the factors inhibiting law enforcement of confiscation of assets resulting from criminal acts of corruption as an effort to recover state losses for the prosecutor's office.

\section{Cultural Factors}

Culture is defined as the mind, reason or customs, grammatically, the notion of culture is derived from the word culture which tends to refer to human thought patterns. It can be said that although nowadays there are many people who have legal awareness, in terms of criminal acts of corruption it has become a growing culture and it remains embedded that the families involved feel ashamed to report it because it will become a family disgrace and seem to be a common act for those who committing a criminal act of corruption [18]. Culture is also one of the important factors in preventing law enforcement of confiscation of assets resulting from criminal acts of corruption as an effort to return state losses to the prosecutor's office, because the culture of corruption causes state assets to be lost more and more, and the number of state losses increases due to the increasing intensity of corruption.

According to Paku Utama, the element of success in making efforts to recover assets resulting from criminal acts of corruption must pay attention to several factors as follows [19]:

1. The perspective on the approach of law enforcement in Indonesia is still focused on punishing the perpetrator (in persona), not taking the proceeds of crime.

2. The need for broader national and international legal instruments regulating asset returns. Legal instruments become a framework regarding the steps that must be taken.

3. The integrity of law enforcers to always prioritize public interests is the main prerequisite so that assets returned are with their original owners.

4. Intensive and sustainable cooperation between law enforcement agencies at the national, bilateral and multilateral levels. To carry out an asset recovery process requires a core team and a task force that has special expertise that functions as the main motor of investigation and prosecution of asset recovery efforts.

5. Consistent political will and strong commitment from the government.

6. International support includes support from countries where assets resulting from corruption are stored. This support is needed since the preventive stage as a criminal policy.

7. The umbrella of international law. Indonesia has ratified the United Nations Convention Against Corruption (UNCAC), United Nations Convention Against Transnational Organized Crime (UNTOC), Asean Mutual Legal Assistance (AMLAT), but Indonesia is not yet a member country of the Organization for Economic Cooperation and Development (OECD).

8. Following up bilateral cooperation with certain countries in handling corruption cases, including extradition, return of assets resulting from criminal acts of corruption, and transfer of assets belonging to other convicted persons.

9. Implementation of automatic exchange of information standards. AEoI is a system that supports the exchange of taxpayer account information between countries at a certain time periodically, systematically, and continuously from the country of source of income or place of storing wealth, to the resident country of the taxpayer.

10. Opening up the possibility in Indonesian criminal law to carry out legal settlement outside the court process (afdoening buiten process) of certain corruption cases.

11. Synchronization and harmonization of laws and regulations. Ratification which is not followed up with harmonization and implementation of the provisions contained in the convention, will have an impact on the Indonesian nation in overcoming, preventing and eradicating corruption in Indonesia. 
12. To gradually revise and/or replace applicable laws and regulations to conform with internationally accepted legal standards; and

13. Immediately promulgating the Draft Law on Confiscation of Criminal Assets, so that there is a special umbrella regarding law enforcement of confiscation of assets resulting from criminal acts of corruption as an effort to recover state losses.

\section{CONCLUSION}

In practice there are several obstacles in enforcing the law of confiscation of assets resulting from criminal acts of corruption as an effort to recover state losses by the Attorney, these obstacles are strongly influenced by legal factors, law enforcement factors, supporting facilities, community factors and cultural factors.

\section{REFERENCES}

1. Kadarudin. (2015). Asset Recovery Hasil Kejahatan Korupsi: Upaya Pengembalian Kerugian Keuangan Negara Melalui Kerjasama Internasional, Makassar: Pustaka Pena Press, p. 87.

2. Syahiruddin, L. (2019). Law Enforcement of Asset Recovery from Corruption Crime by Prosecutor, IOSR Journal of Humanities and Social Science, 24(10), 32.

3. Syed, H. A. (1987). Korupsi Sifat, Sebab dan Fungsi, Penerjemah, Nirwono, Jakarta: LP3ES, p. 7.

4. Riawan, T. W. (2013). Hukum Keuangan Negara, Jakarta: Gramedia Widiasarana Indonesia, p. 78.

5. Refki, S. (2017). Tantangan Penerapan Perampasan Aset Tanpa Tuntutan Pidana (Non-Conviction Based Asset Forfeiture) dalam RUU Perampasan Aset di Indonesia, Jurnal Integritas, 3(1), 118.

6. Peter Mahmud Marzuki, Penelitian Hukum, Jakarta: Prenadamedia Group, 2005, p. 35
7. Kadarudin. (2020). Mengenal Riset dalam Bidang Ilmu Hukum: Tipologi, Metodologi, dan Kerangka, Ponorogo: Uwais Inspirasi Indonesia, p. 171.

8. Wiyono, R. (2014). Pembahasan Undang-Undang Pencegahan dan Pemberantasan Tindak Pidana Pencucian Uang, Jakarta: Sinar Grafika, p. 141.

9. Reports on the Alignment of Academic Texts on the Draft Law concerning Confiscation of Criminal Acts, National Law Development Agency, Ministry of Law and Human Rights of the Republic of Indonesia 2015, p. 9-10.

10. Chaerul, A. (2014). Kejaksaan Memberantas Korupsi (Suatu Analisis Historis, Sosiologis, dan Yuridis), Jakarta: Deleader, p. 91.

11. Romansah, F. (2017). Pelaksanaan Penyitaan Aset Terpidana Korupsi Sebagai Upaya Pengembalian Kerugian Negara (Studi di Kejaksaan Negeri Bandar Lampung).

12. Wahyudi, H. S. (2010). Implikasi Perampasan Aset Terhadap Pihak Ketiga Yang Terkait Dengan Tindak Pidana Korupsi, Postgraduate Thesis, Faculty of Law, University of Indonesia, 2010 in Reports on the Alignment of Academic Texts on the Draft Law concerning Confiscation of Criminal Acts, Loc.Cit., p. 9-10.

13. Reports on the Alignment of Academic Texts on the Draft Law concerning Confiscation of Criminal Acts, Ibid., p. 131.

14. Ibid.

15. Ibid., p. 134

16. Kristian \& Gunawan, Y. (2015). Tindak pidana korupsi: Kajian terhadap harmonisasi antara hukum nasional dan the united nations convention against corruption (UNCAC). Bandung: Refika Aditama.

17. Fauzul Romansyah et al., Loc.Cit., p. 7.

18. Ibid.

19. Paku, U. (2013). Memahami Asset Recovery dan Gatekeeper, Jakarta: Indonesian Legal Roundtable, p. 80 . 